\title{
Assessment of The Renewable Energy Offshore and Wind Energy Markets Affects During The COVID-19 Virus
}

Riaz Hussain Jamali

Sichuan University

Amanullah Bughio

Sichuan University

Ghansham Das

Sichuan university

Rizwan Jamali

Sindh Agriculture University

Shova Niroula

NUAA: Nanjing University of Aeronautics and Astronautics

\section{Zulfiqar Ali Baloch ( $\sim$ balochzulfiqarali@nuaa.edu.cn )}

Nanjing University of Aeronautics and Astronautics College of Economics and Management https://orcid.org/0000-0003-4911-3017

\section{Research Article}

Keywords: Wind and offshore energy, Levelized Cost of Energy, COVID-19 Pandemic, Renewable energy

Posted Date: November 22nd, 2021

DOI: https://doi.org/10.21203/rs.3.rs-1008101/v1

License: (c) (1) This work is licensed under a Creative Commons Attribution 4.0 International License. Read Full License 


\section{Abstract}

The main aims of the current study are to determine during the COVID-19 epidemic effects on renewable and green energy and control the raising the cost of utilizing renewable energy to power for country energy plants using the Levelized Cost of Energy methods. Objective 1) The COVID-19 pandemic can be provided through green financial policies such as coal pricing, transferable green certificates, and loans for renewable energy markets. Objective 2) examined the cost of offshore wind power in china before and after the COVID-19 outbreak, using data from 100 offshore wind power projects constructed between 2000 and 2020. Based on results, wind power's fixed average cost of electricity fell from 0.98 Chinese yuan in 2000 to 0.79 Chinese RMB in March 2019, and subsequently to 0.75 Chinese RMB in 2020, a 13.99 percent increase. Other results average electricity generation price down to $0.79 \mathrm{RMB}, 0.99 \mathrm{RMB}$, and $0.79 \mathrm{RMB}$ and average carbon oxide emissions was $50 \mathrm{RMB} /$ ton increase. The green fiscal policies will be required during the COVID-19 epidemic to promote offshore wind energy generation investment.

\section{Introduction}

Due to technological advances, wind power has become an increasingly significant factor in China's renewable energy system. Consumer capitalization power is critical to China's energy transformation and climate change mitigation (Tu et al. 2019b; Banerjee et al. 2021). Despite the positive outlook for China's offshore wind power, there are many difficulties in expansion, including offshore wind curtailment, restricted building Land, audibility (Zhao et al. 2013; Kuzemko et al. 2020). owing to the qualities because there is no one else on the land, there is a lot of wind, and there isn't anyone else around proximity to the electrical load recent renewables has generator steady (Mattar, Guzmán-lbarra, 2017). Since the last few years, wind farm investment costs generation has defrosted dramatically to advancements in scale economies and technology. The installed capacity of offshore wind power in China rose from $0.16 \mathrm{GW}$ in 2010 to $6.49 \mathrm{GW}$ in 2019.

Despite advancements in technology and economies of scale, the development cost of offshore wind turbines in China has decreased since the conclusion of the COVID-19 epidemic in 2015. The cost of a kilowatt-hour is between 6,000 and 7,000 yuan, depending on the region (Sherman et al. 2020). 1 In addition, as a result of the impact of the epidemic of wind turbines, the insufficient capacity of new wind turbines has resulted in the outbreak of COVID-19, which has been linked to the outbreak of wind turbines (Wiser et al. 2016). Additionally, the delivery invoice (FIS) is used in the offshore wind energy processing industry. The "installation value" of offshore wind turbines in China will continue to climb as the demand for these turbines grows (Chen et al. 2020; Zhou et al. 2021). (Zhang et al. 2020). Finally, because of the detrimental impact of COVID-19 on the Chinese economy and the rise in systemic worries in the financial sector, wind projects generation cost rise (Grunewald 2017). As a result, it is predicted that China's offshore wind power sector will decrease more. COVID-19 is expected to have a detrimental impact on the wind energy sector. Green financing, which provides low-cost finance for the development and operation of renewable energy, can assist mitigate this impact. This supports the development of offshore wind energy projects (Ouyang and Lin 2014). Provide green certificates, carbon offsets, and green transferable 
credits, as well as green transferable credits. TGC is one of China's most widely used green economy policy instruments, and it is divided into three sections. China, from coal to coal, coal to coal, and co coal (Liang and., 2019). Eight local coal markets have been este cities such as Beijing, Tianjin, Zhejiang, Hubei, Guangdong, Chongqing, and emissions mentioned above to the national carbon market were declared in (Mattar and Guzmán-lbarra 2017). The federal carbon market will begin trial (Ligus 2014)with the adoption of NDRC's "Measures for the Management of Carbon Emissions Trading" (Li et al. 2018). Second, the Chinese TGC market is still in its early stages. TGC prices fluctuate significantly due to the lack of a well-developed pricing mechanism, ranging from 128.6 to $382.3=(T u$ et al. 2019a). By the end (Irawan et al., 2017), China will have issued more than 20 million TGCs for wind power, with a trading volume of around 73000 . Finally, green credit has grown in popularity in recent years. According to the People's Bank of China's "Green Finance Development (Lutzeyer et al. 2018), China's green credit has climbed from 2.9 trillion (Tu et al. 2019b)to 12 trillion(Da et al. 2011), with the share of green credit invested in clean energy increasing from 7.2 (Tu et al. 2019b).to 10. (Davidson et al. 2016).

According to several studies, cost reductions in offshore wind power projects during the last decade are due not just to technological advancements and to increased funding circumstances initiatives involving offshore wind power (Yuan 2016). Green finance can provide lower-cost financing as well as revenue offshore wind power project investment and operation. For instance, in the case of carbon pricing strategy, investors in wind farms off the coast can sell issued certified emission reduction (CERs) and receive emissions reduction revenues at a specific carbon price to offset the increased investment costs of offshore wind power projects because of the COVID-19 pandemic. However, because China's green financing system is still in its early stages, the impact of green finance policies on stimulating offshore wind power investment has been lightly studied, particularly considering the COVID-19 pandemic. To fill the literature gap, the influence of the COVID-19 epidemic on the cost of offshore wind energy projects is investigated first. Green finance measures, such as carbon pricing, tradable green certificates, and green credit, were then added into the evaluation of the wind added toess of green finance evaluation in mitigating COVID-19's adverse effects was wireless. Third, the essential values of policies and the policy mix of green finance policies to promote investment in offshore wind power are expanding. Determines reasonably as policy recommendations for improving China's current green financing system.

This paper's reminder is organized as follows. The second section is devoted to a review of the literature. Section 3 introduces the technique used in this paper. The data is described in Section 4. The results are presented in Section 5. Section 6 contains a summary of the findings.

\section{Literature Review}

This section reviews significant studies on the cost of offshore wind generation, the impact of the Covid19 epidemic on renewables, and green finance in China. Based on which the existing studies' research gaps are identified, and the main contributions are clarified. The cost of renewable energy must be assessed. Understanding renewable energy grid parity and cost evolution in the future (Bosch et al. 2019; Broto and Kirshner 2020; Kuzemko et al. 2020) As a result, cost evaluation of wind power has become a 
research focus. Worldwide, wind power technology has progressed. Electricity at a Levelized Cost (LCOE)is extensively used to analyze the cost-effectiveness of renewable energy power (Hosseini 2020; Rosenbloom and Markard 2020; Quitzow et al. 2021) as a way to evaluate the costs of power production systems across their whole lifetime (Cui et al. 2020; Sovacool et al. 2020) first conducted a systemic analysis of Chinese onshore wind's LCOE generation, finding that it ranged from 0.52 to $0.61 \mathrm{CNY} / \mathrm{kWh}$ when using a $4 \%$ discount rate (Yoshino et al. 2021), estimated the LCOE of wind electricity on average in six Chinese cities Tongliao, Zhangjiakou, Chaoyang, Qingdao, Jiujiang, and Quanzhou are some of the cities in China. The LCOEs were between 0.38 and $1.04 \mathrm{CNY} / \mathrm{kWh}$.(Gillingham et al. 2020) used the LCOE model to examine the projected. In China, the cost of offshore wind power has risen. Finding predicted the price of offshore wind power in China would drop from 0.40 yuan per kWh of electricity to 20 yuan/kilowatt-hour (Barbier 2020).to 0.35 yuan/(Hafner et al. 2020). Researchers have been paying close attention to the Offshore wind's cost evolution generation as the technology has progressed.

Existing studies are listed in Table 1. examine the operation and maintenance have an impact costs, connection to the grid costs, The impact of the discount rate, as well as other factors, on the ultimate cost of offshore wind energy in various countries, and examine how operation and maintenance expenses, grid connection prices, the discount rate, and other factors affect the overall cost of offshore wind production. (Falcone and Sica 2019; Bourcet and Bovari 2020). The findings show that offshore wind power costs have dropped rapidly in the United Kingdom. Offshore wind power can now compete with traditional fossil energy power in the United Kingdom, Denmark, and other European countries, and offshore wind power can now compete with contrast, typical fossil energy power, offshore wind power costs in Japan, United States, and other countries remain higher than traditional fossil energy power. The growth of offshore wind energy in China has gotten a lot of attention in recent years, thanks to the Offshore wind power capacity is gradually increasing. According to relevant research, China's majority of offshore wind energy resources are located towards the eastern coasts of the country, with enormous development and usage potential(Ouyang and Lin 2014; Davidson et al. 2016; Tu et al. 2019b). However, due to the connection of the grid restrictions, Key technology for operation and maintenance (Sherman et al. 2020), the cost of offshore wind generation remains greater than in the developed countries mentioned above. 
Table 1

List of studies RE wind generation.

\begin{tabular}{|c|c|c|c|c|c|}
\hline Region & Time & Data sources & Cost & Key factors & The references \\
\hline The U.S. & 2012 & Level 4 wind farm & $\begin{array}{l}0.14-0.32 \\
(\dot{\$} / \mathrm{kWh})\end{array}$ & Tax rate, $0 \& M$ cost & $\begin{array}{l}\text { (Zhang et } \\
\text { alThe ., 2019) }\end{array}$ \\
\hline U.K. & $\begin{array}{l}2012- \\
\text { Ten0 }\end{array}$ & $\begin{array}{l}10 \text { wind power } \\
\text { projects }\end{array}$ & $\begin{array}{l}0.18-0.11 \\
(£ / k W h)\end{array}$ & $\begin{array}{l}\text { Discount rate, capacity } \\
\text { factor }\end{array}$ & $\begin{array}{l}\text { (Anser et al. } \\
\text { 2020) }\end{array}$ \\
\hline Global & $\begin{array}{l}2014- \\
2050\end{array}$ & IEA & $\begin{array}{l}0.19-0.10 \\
(\$ / \mathrm{kWh})\end{array}$ & $\begin{array}{l}\text { Capacity factor, } \\
\text { discount rate, O\&M cost }\end{array}$ & (Volz 2018) \\
\hline E.U. & $\begin{array}{l}2000- \\
2015\end{array}$ & $\begin{array}{l}46 \text { wind power } \\
\text { projects }\end{array}$ & $\begin{array}{l}0.10-0.25 \\
(€ / \mathrm{kWh})\end{array}$ & $\begin{array}{l}\text { Capacity factor, } \\
\text { resource potential }\end{array}$ & $\begin{array}{l}\text { (Nicita et al. } \\
\text { 2020) }\end{array}$ \\
\hline Chile & $\begin{array}{l}1979- \\
2014\end{array}$ & $\begin{array}{l}\text { Resource } \\
\text { potential }\end{array}$ & $\begin{array}{l}0.10-0.11 \\
(\$ / \mathrm{kWh})\end{array}$ & $\begin{array}{l}\text { Initial cost, capacity } \\
\text { factor, discount rate }\end{array}$ & $\begin{array}{l}\text { (Singh et al. } \\
2020)\end{array}$ \\
\hline $\begin{array}{l}\text { Canary } \\
\text { Islands }\end{array}$ & 2014 & $\begin{array}{l}\text { Resource } \\
\text { potential }\end{array}$ & $\begin{array}{l}0.18-0.26 \\
(€ / \mathrm{kWh})\end{array}$ & $\begin{array}{l}\text { Power generation, grid } \\
\text { connection cost }\end{array}$ & (Lv et al. 2021) \\
\hline Global & $\begin{array}{l}2000- \\
2018\end{array}$ & IRENA & $\begin{array}{l}0.13-0.13 \\
(\dot{\$} / \mathrm{kWh})\end{array}$ & $\begin{array}{l}\text { Capacity factor, unit } \\
\text { investment cost }\end{array}$ & $\begin{array}{l}\text { (Dikau andThe } \\
\text { Volz, 2018) }\end{array}$ \\
\hline U.S. & - & $\begin{array}{l}\text { Resource } \\
\text { potential }\end{array}$ & $\begin{array}{l}0.12 \\
(\dot{\$} / \mathrm{kWh})\end{array}$ & $\begin{array}{l}\text { Investment cost, O\&M } \\
\text { cost, discount rate }\end{array}$ & $\begin{array}{l}\text { (ZhaThe ng et } \\
\text { al., 2021) }\end{array}$ \\
\hline The U.K. & & & $\begin{array}{l}0.07 \\
(\$ / \mathrm{kWh})\end{array}$ & & \\
\hline Japan & & & $\begin{array}{l}0.09 \\
(\$ / k W h)\end{array}$ & & \\
\hline Denmark & - & $\begin{array}{l}\text { Resource } \\
\text { potential }\end{array}$ & $\begin{array}{l}0.09-0.17 \\
(€ / \mathrm{kWh})\end{array}$ & $\begin{array}{l}\text { Investment cost, } O \& M \\
\text { cost, discount rate }\end{array}$ & (Finance 2013) \\
\hline \multirow[t]{2}{*}{ China } & \multirow[t]{2}{*}{-} & \multirow{2}{*}{$\begin{array}{l}\text { Zhejiang Putuo } \\
6 \# \text { wind project }\end{array}$} & 0.56 & \multirow{2}{*}{$\begin{array}{l}\text { Investment cost, } \\
\text { operation hour, lifetime }\end{array}$} & \multirow{2}{*}{$\begin{array}{l}\text { (Rehman et al. } \\
\text { 2021) }\end{array}$} \\
\hline & & & (CNY/kWh) & & \\
\hline
\end{tabular}

\subsection{The effect of the Covid-19 on renewable energy financial markets}

The global growth of renewable energy has faced significant hurdles since the advent of the COVID-19 pandemic(Shafiee et al. 2015; Sherman et al. 2020). To begin, governments in various countries have implemented policies to limit the cross-border movement of people and create appropriate preparations for businesses to resume operations to stop the COVID-19 epidemic from spreading. These measures have to raise the cost of living energy trial renewable energy's burden enterprises and postpone renewable energy power projects investment in the renewable energy power industry (Sutherland 2019; Praveen et al. 2020). Second, the COVID-19 epidemic could affect renewable energy manufacturing supply networks, which has hindered the move to renewables (Tu et al. 2021). Third, because of the COVID-19 epidemic, 
the Renewable energy power equipment imports and exports have been halted, delaying the gridconnection renewable energy sources, and increasing the danger of renewable energy investment. As a result, the COVID-19 pandemic is widely regarded as having a negative impact on current investment in renewable energy

\subsection{Renewable energy investment}

Green finance is a new type of financial It is the apex of financial innovation in the renewable energy sector, and it was created to address environmental challenges. Sector (Ouyang andeconomic4) Various financial policy instruments, such as carbon pricing, tradable green certificates, and green credit, have been proposed to boost renewable energy investment alongside the development of green financing. The positive influence of green finance on renewable energy investment, notably in wind energy, has long been demonstrated. (Zhao et al. 2016)and biomass energy(He et al. 2016). Green finance policies, in particular, might hasten the transition from traditional to by providing direct or indirect economic incentives for renewable energy, as well as lowering the overall cost of renewable energy generation (Zhao et al. 2013; Tu et al. 2019b; Praveen et al. 2020)

\subsection{Research main Contribution}

Unlike earlier research, this work makes a two-fold contribution. First, recent studies have focused on China's offshore wind resource distribution, focusing on assessing the potential for cost reductions in offshore wind power focusing. Just a little research on the cost of offshore wind exists. Generation in China that is based on actual investment and operation indeed, because of disparities in Varied regions of China have different levels of growth and offshore wind resources. There is a significant cost gap in offshore wind generating projects, which the COVID-19 epidemic may exacerbate. As a result, we calculate the LCOE of offshore wind power based on a set of assumptions to represent the cost evolution of Chinese offshore wind farms. A comprehensive selection of offshore wind power projects more positively in China (Lin and Zhu 2019; Ghorbanpour et al. 2021), and we examine the Covid-19's impact on the cost evolution of offshore wind generation has never been investigated to our knowledge. Second, this study quantifies the importance of green financing in reducing the harmful consequences of climate change. The COVID-19 pandemic on offshore wind power investment, focusing on Carbon pricing, tradable green certificates, and green credits are all ideas that may significantly impact policy in the future-design to promote renewable energy investment significantly impacted.

\section{Methodology}

The Levelized Cost of Energy (LCOE) is a calculation that determines the average cost of power production by dividing the entire cost of constructing and running a power plant by the total energy output throughout the project's lifespan. It's now a well-known measure for evaluating the prices of power generated by various energy systems (Ibiang et al., 2017; Yaghoubian et al., 2021). The LCOE may alternatively be thought of as the lowest price at which energy must be sold for the project to break even throughout its lifespan. When the present value of total discounted revenues () matches the total 
discounted cost throughout the system's lifespan, the LCOE is computed ( $\mathrm{N}$ years). The formula for calculating the Present Net Value (NPV) is as follows:

$N P V=\sum_{i-1}^{N} \operatorname{Cash}(i) \%(1+d)^{-i}=0$

Where $\mathrm{d}$ is the discount rate, and I am the cash flow in a during the covid-19 year I, which is represented as follows:

$\operatorname{cash}(\mathrm{i})=\mathrm{E}(\mathrm{i}) \% \mathrm{P}+\mathrm{D}-\mathrm{I}-\mathrm{o \& M}(\mathrm{i})-\mathrm{L}(\mathrm{i})-\mathrm{t}(\mathrm{i})(2)$

In particular, is the yearly energy output in the year I, which can be computed using the capacity, the capacity factor, the offshore wind turbine utilization rate, and the capacity factor. Maximum is the on-grid price of wind electricity and is the available utilization hours in a typical year (8760h), assuming a fixed fee for the duration of the project When the whole NPV (including prepaid investment and debt, capital cost, $O \& M$ cost, loan payment, and tax) equals zero, the investment is considered successful. This price has been established. Is the project's investment costs, is the project's operation and maintenance (O\&M) costs, and is the project's tax cost in year one, which comprises VAT, IBT, and education costs, a surtax on urban development. In addition, the bank loan is e and $80 \%$ of the investment cost, i.e., the debt. As a result, with a loan period of (Lv et al. 2021), the loan payment may be written as

$\mathrm{L}(\mathrm{r})=\frac{D \% r \%(1+r)}{(1+r)^{1}-1}$

The break-even power price, at which the NPV equals zero, and the investor gets a return proportionate to the discount rate, is known as the can figure it out. LCOE using.

$\operatorname{LCOE}=\left(I+\sum_{=1}^{n} \frac{o \& M(i)+L(r)+T(i)-D}{(1+d)}\right) /\left(\sum_{i=1}^{N} \frac{Q^{\prime \prime} \% C F \% 8760 \% \theta^{\prime}}{(1+d)}\right)$

This document assesses the cost of electricity generation for green finance. Green loans, carbon pricing, and green certificates for sale are three e financial goods in general. As indicated in the equation, institutional investors in offshore available e wind turbines may be eligible to flex loan interest rates through commercial bank green loans and loan repayments. (3) More Invest in renewable energy and decrees the emissions and issued in the first year and profit from emission reductions under the carbon dioxide pricing plan. Finally, offshore wind energy investors can issue green certificates in the transferable green certificate (TGC) market to gain additional revenue. On the invoice from TGC. As a result, equation (4) power generation cost (4) may be written as follows:

\section{$L C O E=\left(I+\sum_{i=1}^{N} \frac{o \& M(i)+L\left(r_{g}\right)+T(i)-D-R_{c}(i)-R_{T G C}(i)}{(1+d)}\right) /$}

$\left(\sum_{i=1}^{N} \frac{Q \% C F \% 8700 \% \theta^{i}}{(1+d)}\right)$ 
This section discusses data sources, capital expenditures, power generation costs, administrative and operating costs, and other financial aspects that have been considered when determining the company's LCOE. Projects to generate electricity wind turbines off the coast of the United States. In addition, Sections 4.6 Feed-in tariffs and 4.7 Green funding discuss offshore wind generation feed-in tariffs and green finance legislation.

\subsection{Data sources}

The information contained in this section mainly comes from (EAP) and (WTTD). We collect essential financial EAP, and WTTD provides technical information for offshore wind power project development progress, wind turbine bid prices, capital costs, and capacity. For example, we are borrowing interest rates. As shown in Figure 1, the data set includes 97 offshore wind farms in Fujian, Guangdong, Zhejiang, Jiangsu, Liaoning, and Shanghai. These projects have the total capacity of previously approved offshore wind power projects, with a total capacity of $28.24 \mathrm{GW}$, accounting full $1 \%$ of the total capacity. Therefore, the data set correctly maps China's offshore wind power industry.

\subsection{Power generation}

It is defined by the maximum capacity, the capacity maximum consumption hours ( 8760 hours) of an offshore wind farm over the conditions such as high temperatures and high humidity overbore wind farms' operational efficiency to decline after year. This is because offshore wind turbines are becoming less efficient. Degradation rates are used to measure because graphic factors on offshore wind turbines' performance, and they are expressed as a percentage. In this post, we will learn more about the $97 \%$ utilization rate. By contrasting the locations of offshore wind farms, you can determine the capacity factor and the amount of offshore wind energy produced by each project. According to government data, it is estimated that the average cost of running and offshore wind farms in China is 0.15 Renminbi per kilowatt-hour. Unfortunately, we are unable to compile figures on the operational expenses of offshore wind generation.

\subsection{Financial parameters}

Bank commercial loan interest rates have a significant impact on LCOE. According to the central bank energy company's benchmark interest rate, the loan interest rate for offshore wind power projects is $4.9 \%$ per year. Fifteen years have passed. Measuring the discount rate of the cost of capital related to technology and time is another important part of determining the LCOE. In this study, the discount rate is set at $6.50 \%$. In order to support the development of offshore wind power technology, the National Development and Reform Commission lowered the offshore grid electricity price in 2019, 2020 to 0.80 yuan/kWh and 0.75 yuan/kWh, respectively (Table 2). 
Table 2

China's feed-in tariffs for offshore wind

energy.

\begin{tabular}{|lll|}
\hline Type & Type & Type \\
\hline offshore wind power & 0.88 & 2014.6 \\
& 0.9 & 2019.7 \\
& 0.79 & 2020.1 \\
\hline
\end{tabular}

The cost of offshore wind turbines, installation, design, and building of wind turbines, and other auxiliary expenditures are all included in the pricing of offshore wind generating projects. Figure 3 depicts the unit investment cost of offshore wind generation projects. From 23,829.20 yuan in 2007 to 17,260.30 yuan in 2019 , the cost per kilowatt has increased. The new investment cost per kilowatt is $23,829.20$ yuan, as illustrated in Figure 3. York. RMB 17,260.30/kW in 2007 has risen to RMB 17,260.30/kW in 2019. However, following the Covid-19 virus outbreak in 2018, the average bid price of offshore wind turbines increased by 10.2 percent in 2019, from RMB 6,312.04/kW in 2018 to RMB 6,955/kW in 2019, as shown in Fig. 2. In 2020, the average single-machine investment cost would be 20327.77 yuan/kw, up $17.41 \%$ from 17,260.30 yuan/kw in 2019. This is because the cost of wind turbines has risen. As a result, Covid19 raised the price of wind turbines on the market, resulting in higher investment expenses.

Green finance is a monetary policy instrument that may be used in the United States to offer financial support for investment and project activities. Some topics include environmental preservation, energy conservation, renewable energy, green transportation, and green buildings. Three representative political methods are green credit, carbon pricing, and tradable green certificates. Green credit is a policy tool in which commercial banks grant preferential loans to low-carbon industry investors. Green finance has grown fast in China since the China Banking Regulatory Commission is in charge of overseeing the banking industry in China (CBRC) released green credit rules in According to the China Central Bank's "Statistical report on financial institutions' loan investments," green credit climbed in CNY from 5.20 trillion to 9.00 trillion 2018, with renewable sources of energy accounting for around $23 \%$ of total green According to we chose eight In our study, preferred loan interest rates were found to be $5 \%, 10 \%, 15 \%$, and $20 \%$, and \% lower. Another green finance strategy for promoting offshore wind production is the price of carbon dioxide. Wind energy investors can sell CER-issued certificates and profit from emission reductions once China's domestic coal market is created. A commercial market for carbon dioxide emissions was established in 2017. The revenues from the removal of emissions might cover some of the costs of offshore wind power generating. Based on the outcomes of China's carbon dioxide pricing pilot program, we determined a carbon dioxide value between 10 and 150 yuan per tonne of carbon dioxide in Section 5. This price range approximately correlates to changes in carbon dioxide prices in China's carbon market. China has an emerging green financial instrument called a specialized green certificate (TGC) used for sales pilots (National Development and Reform Commission, 2017b). An earlier draft, unlike FIT, is a market-based program that can incentivize diverse users to purchase renewable energy power in the electrical market. Renewable energy generators, in particular, can sell granted green 
certificates on the TGC industry are expected to create extra cash because of their renewable production. In this situation, the earnings from TGC sales can help offset some Understanding of the expenses of generating offshore wind power. By June 2020, China will have issued 5,681,112 TGCs for wind power, with a trading volume of 37,750 . TGC is also available in wind power, with a price range of $128.60-273.70$ yuan. The price of TGC in this article is between 130 and 270 yuan (roughly) and is closely linked to the cost of transferable green certificates on the Chinese market.

\section{Results And Discussion}

The cost of generating electricity offshore wind turbines is estimated. Part 4 of the Covid-19 pandemic provides information about the economics of offshore wind power. In contrast, part 4 of the Covid-19 pandemic section 3 provides information about the economics of offshore wind power generated using, in contrast, described. Section 5 examines the role of green finance in reducing the life cycle cost of offshore wind power projects. 2 . The impact of the policy mix on green capital and the profitability improvement plan of offshore wind power projects should be formulated following the actual coexistence of policy tools.

\subsection{Analysis impacts of Covid-19 on the cost of offshore wind power plants}

The average LCOE of wind power dropped from RMB 0.86/kWh in 2014 to RMB 0.72/kWh in 2016, a sharp drop of $16.17 \%$. Since the emergence of Covid-19, the construction of offshore wind turbines has suffered losses, resulting in reduced efficiency of wind turbines and rising prices of offshore wind turbines. Therefore, by 2020 , the average LCOE will increase by $10.84 \%$ to 0.79 yuan $/ \mathrm{kWh}$. The LCOE of the 20 projects in 2019 is lower than the FIS ( 0.75 yuan/ $\mathrm{kWh}$ ) in Figure 4, indicating that most of the projects will be profitable. Only three of the 19 projects will be profitable. Starting in 2020, the Covid-19 pandemic will be lower than FIS, which means that only $3 \%$ or $16 \%$ of companies will be profitable. In addition, the outcome of the Covid-19 pandemic will vary depending on your location, and average results LCOE Zhejiang province increased by $3.25 \%$.

COVID-19 insulating standards, on the one hand, stymie the development of offshore power plants. The project's progress was postponed by the employees. COVID-19The employees postponed the project's progress certainty among stockholders who are interested in future cash flows. You may be hesitant to invest in offshore wind power projects due to unclear financial restrictions and restricted availability. Furthermore, the present COVID-19 offshore wind turbine pandemic has gotten more unstable as the offshore wind turbine supply chain grows more international. Finally, the COVID-19 outbreak can potentially raise the cost of wind energy for maritime can potentially.

\subsection{Green financing strategy and the LCOE of offshore wind generating}


Section 4.7 describes how green tax policies may promote access to low-cost financing and extra offshore investment and revenue while also lowering the Levelized cost of energy (LCOE) and increasing the profitability of offshore wind generating projects. Offshore wind farms are being affected by the COVID-19 pandemic. The life cycle cost of offshore wind farms with environmentally friendly financing alternatives, as well as the 19 life cycle cost lines of the 19 offshore and scheduled to be built by 2020, is shown. The cost of electricity is $0.68 \mathrm{yuan} / \mathrm{kh}$ and $0.69 \mathrm{yuan} / \mathrm{kWh}$ (Changle Farm offshore wind power). C) 19 wind farms (Mainland Changle $C$ Wind Farm) with a cost of 0.86 yuan per kilowatt-hour of electricity C Wind Farm Project). In 2020, the difference between Changle C offshore wind farm and Bandon III offshore wind farm (Changle $\mathrm{C}$ offshore wind farm) was 0.68 yuan/kWh (Changle $\mathrm{C}$ offshore wind farm) (Banton III offshore wind farm). By 2020, the average fixed cost and fixed power cost (LCOE) of 19 offshore wind turbines will be 0.79 yuan $/ \mathrm{kWh}$ and $0.79 \mathrm{yuan} / \mathrm{kWh}$, respectively, according to the National Renewable Energy Laboratory. Compared to FIS ( 0.75 yuan/kWh), LCOE will only be able to build or compare or wind power projects by 2021. 2020 will see a rise in coal prices from 0 to 50 yuan as an increase in lucrative projects from three-sevenths to $100 \%$. (to). And the cost of carbon dioxide is growing under China's emissions trading pilot progress. According to the World Bank, thee. After reaching 100 yuan per tonne in the coal pilot project, average Levelized cost of electricity) drops to 0.72 yuan per hour of Electrocoated, increasing the number of viable projects from 12 to 14. Investors in offshore wind turbines get low-interest commercial bank loans under the Green Credit Program, allowing them to reduce their loan repayments. The average fixed energy cost decreased from 0.79 yuan $/ \mathrm{kWh}$ to $0.74 \mathrm{yuan} / \mathrm{kWh}$. The number of winning bids fell from 3 to 11, and the benchmark loan interest rate was cut by 20 percent due to these changes in Twenty-one commercial banks in China recorded the loans.

Twenty-one commercial banks in China reported the lowest interest rate on long-term loans, a 40 percent drop from the previous month's benchmark rate. The average Levelized cost of energy (LCOE) will be decreased to 0.69 yuan/kWh to ensure overall profitability. It is the year 2020. Following data, great laws such as coal pricing, commercial greed green loans have contributed to the reduction of energy prices and the growth in the profitability of offshore wind projects. According to our study, offshore wind energy prices range between $0.79 \mathrm{yuan} / \mathrm{kWh}$ and $0.76 \mathrm{yuan} / \mathrm{kWh}$, and offshore wind energy prices ranger.

\subsection{Offshore wind farm life cycle costs under various policy scenarios}

It is also investigated if the combination of green tax policies would influence lowering fixed energy prices for offshore wind generating projects in 20influenceAccording to 19 alternative policy scenarios, the distribution of LCOE projects is depicted in Fig. 3. Figure 3 illustrates the entire life cycle costs of 19 offshore wind generating projects in 2020, including green credits and carbon benchmark prices and green certificates and carbon bench including). According to Electra and the calculator's fixed cost, the rate is between 0.68 and 0.86 yuan/ $\mathrm{kWh}$, which is lower than the benchmark rate. The average loan cost of energy (LCOE) (0 percent GCR) was 0.79-0.68 yuan/kWh, representing a reduction of 13.85 percent. Take, for example, a rise in the price of $\mathrm{CO}_{2}$ from zero to 150 yuan per ton (Case CP 0). (CP 150 is the case number in this instance.) If the reference interest rate of the loan is 10 percent (GCR -10 percent), 20 
percent (GCR -20 percent), 30 percent (GCR -30 percent), or 40 percent (GCR -40 percent), the loan is considered to be in default (GCR). In the case of 40 percent), the average LCOE is 0.76 yuan $/ \mathrm{kWh}, 0.73$ yuan/kWh, 0.70 yuan/kWh, 0.68 yuan/kWh, and 0.66 yuan/kWh, respectively (Table CP-150). Chinese carbon trading market participants can emit up to 0.66 yuan $/ \mathrm{kWh}$ of carbon dioxide, $0.062 \mathrm{yuan} / \mathrm{kWh}$, 0.60 yuan $/ \mathrm{kWh}$, and 0.58 yuan $/ \mathrm{kWh}$ of carbon cannier discretion. LCOE will fall by 14.33 percent, 14.83 percent, 15.35 percent, and 15.88 percent if there is no $\mathrm{CO}_{2}$ pricing system, and LCOE will decrease by 14.83 percent if there is no $\mathrm{CO}_{2}$ price system (Case CP-0). In 2020, the price of the LCOE 19 offshore wind power project will vary between 0.68 yuan/kWh and 0.86 yuan $/ \mathrm{kWh}$, depending on the mix of environmental protection and green letters of credit. (It also has the option of being converted into $\mathrm{RMB} / \mathrm{kWh}$ ). Furthermore, there are just three offshore wind energy projects now under construction. It has a CCR of zero per cent, making it acceptable for usage. The average Levelized cost of capital (LCOE) for TCOC (Box TGC-130) is 130 yuan. So, the credit reference rate is decreased by 0 per cent in the GRC case, then by 10 per cent in the GRC case, then by 20 per cent in the GRC case, then by $30 \%$ in the GRC case, then by $40 \%$ in the GRC case. (GRC accounted for $40 \%$ of the total). The RMB/kWh, the RMB $0.53 / \mathrm{kWh}$, and the RMB $0.0 / \mathrm{kWh}$ all fell by 23.90 percent, 24.72 percent, and 25.56 percent, respectively, from their previous levels. According to the findings, green credit requirements can increase the efficacy of TGC proposals while also accelerating the decrease of the levelized cost of energy (LCOE) of offshore wind generating plants.

\subsection{The COVID-19 vaccination impacts on financing mechanism}

The names of responders are included in Table 1. "Support the suggested COVID-19 immunization technique. Individuals only need to pay a tiny percentage (6.4 per cent). Although individuals are responsible for the entire cost of the COVID-19 vaccination, the majority of respondents (15.7 per cent) feel that individuals must pay out of pocket. Make a payment for the entire cost of the COVID-19 vaccination. According to 77.9 per cent of respondents, individuals are responsible for a portion of the expenditures associated with COVID-19. Respondents ( 90.9 per cent and 78.0 per cent, respectively) believe that the government and health insurance companies should shoulder a portion of the expense of COVID-19.

Figure 3 and Table 4 illustrates the DAP distribution of O.E. and certain COVID-19 vaccinations compensated in the form of E.O. They will pay you with RMB ten or more for this. The COVID-19 vaccine is an OE-based WTP medium. RMB 100 is the average value, whereas CN4 254 is the average value (SD = 677). The most excellent willingness to pay in the O.E. problem is 10,000 CNY. Since some respondents have a greater desire to pay than the average, the distribution of willingness to pay data is biased to the right, and the average willingness to pay is more significant than the median. Compared to the majority, their stated W. They were much higher (for example, RMB 1,000 and beyond); a more significant proportion of respondents than typical expressed an unwillingness to pay for the COVID-19 vaccination. Self-funded vaccinations for COVID-19 account for approximately $47 \%$ of all immunizations, and the average is $45 \%(S D=22)$. 
Table 3

Shows the self-paid proportions of responders for COVID-19 vaccination.

\begin{tabular}{|c|c|c|c|c|c|c|c|}
\hline \multirow[t]{2}{*}{ WTP values } & \multicolumn{7}{|c|}{ Self-paid \% } \\
\hline & Occurrence & $(\%)$ & $\begin{array}{l}\text { Cumulative } \\
(\%)\end{array}$ & & Occurrence & $(\%)$ & $\begin{array}{l}\text { Cumulative } \\
(\%)\end{array}$ \\
\hline Rejected $^{\text {a }}$ & 179 & 8.7 & 8.7 & $\begin{array}{l}\text { Rejected } \\
\text { a }\end{array}$ & 179 & 8.7 & 8.7 \\
\hline 0 & 20 & 1 & 9.7 & 0 & 38 & 1.9 & 10.5 \\
\hline $1 \sim 9$ & 12 & 0.6 & 10.3 & $1 \sim 9$ & 25 & 1.2 & 11.8 \\
\hline 10 & 51 & 2.5 & 12.7 & 10 & 49 & 2.4 & 14.1 \\
\hline $11 \sim 49$ & 66 & 3.2 & 15.9 & $11 \sim 19$ & 53 & 2.6 & 16.7 \\
\hline 50 & 298 & 14.5 & 30.4 & 20 & 156 & 7.6 & 24.3 \\
\hline $51 \sim 99$ & 37 & 1.8 & 32.2 & $21 \sim 29$ & 127 & 6.2 & 30.5 \\
\hline 100 & 526 & 25.6 & 57.8 & 30 & 101 & 4.9 & 35.4 \\
\hline $101 \sim 149$ & 15 & 0.7 & 58.5 & $31 \sim 39$ & 78 & 3.8 & 39.2 \\
\hline 150 & 52 & 2.5 & 61 & 40 & 177 & 8.6 & 47.8 \\
\hline $151 \sim 199$ & 10 & 0.5 & 61.5 & $41 \sim 49$ & 177 & 8.6 & 56.4 \\
\hline 200 & 382 & 18.6 & 80.1 & 50 & 269 & 13.1 & 69.4 \\
\hline $201 \sim 299$ & 15 & 0.7 & 80.8 & $51 \sim 59$ & 130 & 6.3 & 75.8 \\
\hline 300 & 89 & 4.3 & 85.1 & 60 & 131 & 6.4 & 82.1 \\
\hline $301 \sim 499$ & 24 & 1.2 & 86.3 & $61 \sim 69$ & 117 & 5.7 & 87.8 \\
\hline 500 & 190 & 9.2 & 95.5 & 70 & 39 & 1.9 & 89.7 \\
\hline $501 \sim 999$ & 19 & 0.9 & 96.5 & $71 \sim 79$ & 47 & 2.3 & 92 \\
\hline 1000 & 48 & 2.3 & 98.8 & 80 & 49 & 2.4 & 94.4 \\
\hline $1001 \sim 2000$ & 10 & 0.5 & 99.3 & $81 \sim 89$ & 25 & 1.2 & 95.6 \\
\hline 3000 & 1 & 0.1 & 99.3 & 90 & 3 & 0.2 & 95.7 \\
\hline 5000 & 8 & 0.4 & 99.7 & $91 \sim 99$ & 13 & 0.6 & 96.4 \\
\hline 10,000 & 6 & 0.3 & 100 & 100 & 75 & 3.6 & 100 \\
\hline
\end{tabular}

The WTP value distribution from the P.S. format is shown in Table 3 is 31.1 per cent of those polled said they would be prepared to spend CNY 50 or less for COVID-19 immunization. Furthermore, the percentage of respondents ready to spend CNY 100 and Table 2 shows that CNY 200 accounted for 27.0 percent and 
18.7 percent, respectively, identical to the O.E. format. In both the O.E. and the P.S. formats, the WTP was fairly consistent and durable.

Table 4

Distribution of WTP for COVID-19 vaccination.

\begin{tabular}{|llll|}
\hline & Frequency & (\%) & Cumulative (\%) \\
\hline Rejected a & 179 & 8.7 & 8.7 \\
\hline 0 & 115 & 5.6 & 14.3 \\
\hline 10 & 104 & 5.1 & 19.3 \\
\hline 50 & 419 & 20.4 & 39.7 \\
100 & 556 & 27 & 66.7 \\
\hline 200 & 385 & 18.7 & 85.4 \\
\hline 500 & 130 & 6.3 & 91.7 \\
\hline Willing to pay for any price & 170 & 8.3 & 100 \\
\hline Note: Refused a means of expressing their refusal to be vaccinated. \\
\hline
\end{tabular}

The LCOE of the 19 offshore wind generating projects in 2020. (b). The directions vary, ranging from 0.68 to 0.86 yuan per $\mathrm{kWh}$. There are only three offshore wind power projects. Therefore, the green loans and green market certificates pile up. It will be profitable with a CCR of 0 percent. The loan reference interest rate has been lowered by 1\%. (Case GCR - 0 percent), 13\% (GCR -11 percent), 19\% (GCR -20 percent), 30\% (GCR -31 percent), and 41\% (GCR -39 percent). TGC has an LCOE of 130 yuan (Case TGC 130), with an average value of 0.70 yuan $/ \mathrm{kWh}, 0.68 \mathrm{yuan} / \mathrm{kWh}$, and 0.70 yuan $/ \mathrm{kWh}$ in China. 0-yuan, 70 yuan/kWh Furthermore, the average LCOE of TGC is 270 yuan (case TGC-270), implying that the highest TGC price in China's TGC market is 0.60 yuan/kWh, 0.58 yuan/kWh, 0.55 yuan $/ \mathrm{KWh}, 0.53$ yuan $/ \mathrm{kWh}, 0.50$ yuan/ $\mathrm{kWh}$, and the lowest TGC price is 23.90 yuan $/ \mathrm{kWh}, 0.55$ yuan $/ \mathrm{kWh}$, when compared to the cost of generating electricity 0 TGC). It also indicates that when the benchmark loan interest rate lowers from $1 \%$ to $41 \%$ for the price of TGC CNY 207 (in the instance of TGC-270), the rate of decline in LCOE increases. Furthermore, the findings suggest that the green credit policy can increase the TGC program's efficiency and assist offshore wind turbines in lowering their LCOE more quickly.

\subsection{Analysis of Sensitivity}

In table 7 Carbon and TGC levels are significant. They are the most important political problem in ensuring that wind energy projects are profitable. There are many important factors to consider, including the size of the wind turbine. The cost and profitability of wind energy are affected by the efficiency and utilization of offshore wind energy, the cost of offshore wind energy, and the status of offshore wind resources (Tu et al. 2019a; Sherman et al. 2020). Depending on the conditions. As a result, $\mathrm{CO}_{2}$ and TGC 
pricing are required in order for any project to be viable. Table 6 and Figure 4 illustrate the results for various parameter assumptions.

Table 5

Key parameter sensitivity.

\begin{tabular}{|lllll|}
\hline Variables & Values & $\begin{array}{l}\text { Avg. } \mathbf{L C O E} \\
(\mathbf{C N Y} / \mathrm{kWh})\end{array}$ & $\begin{array}{l}\text { carbon price required } \\
(\mathrm{CNY} / \mathrm{t} \mathrm{CO})\end{array}$ & $\begin{array}{l}\text { TGC price required } \\
(\mathrm{CNY})\end{array}$ \\
\hline $\begin{array}{l}\text { O\&M costs } \\
(\mathrm{CNY} / \mathrm{kWh})\end{array}$ & 0.1 & 0.74 & 62.24 & 75.52 \\
\hline & 0.12 & 0.76 & 94.93 & 107.72 \\
\hline & 0.15 & 0.79 & 143.97 & 156.01 \\
\hline $\begin{array}{l}\text { Utilization rate } \\
(\%)\end{array}$ & 90 & 1.13 & 185.59 & 236.51 \\
\hline & 95 & 0.88 & 673.46 & 685.18 \\
\hline & 97 & 0.79 & 284.22 & 296.19 \\
\hline $\begin{array}{l}\text { ICapacity factor } \\
\text { (\%) }\end{array}$ & 30 & 1.06 & 143.97 & 156.01 \\
\hline & 39 & 0.92 & 12.21 & 24.34 \\
\hline & 40 & 0.79 & 487.02 & 498.82 \\
\hline & 45 & 0.76 & 272.55 & 284.51 \\
\hline
\end{tabular}

Operators must first address the issue of predictability in offshore wind generation, resulting in increased operating and maintenance expenses (Tu et al. 2019a; Sherman et al. 2020). The operation and maintenance resulting sensitivity analysis will determine each offshore wind farm's $\mathrm{CO} 2$ serenity and needed value. We picked 0.1 yuan/kWh for the small scenario and 0.2 yuan $/ \mathrm{kWh}$ for the big case, based on the difference between the two (EMI, 2014). During the same period, the average cost of offshore wind power climbed from 0.74 yuan per $\mathrm{kWh}$ to 0.85 yuan, while the average running price went from 0.10 yuan per kWh to 0.20 yuan per kWh. Maintaining the facility has become more expensive than planned, as indicated in Table 3.

With regard to offshore wind power, the cost of electricity generation has a more significant impact. To better understand the viability of offshore wind power projects, we assessed the LCOE of 19 offshore wind power projects in 2020, with the current FIS being 0.75 yuan $/ \mathrm{kWh}$. The $\mathrm{CO}_{2}$ price ranges from 62.24 yuan per ton of $\mathrm{CO}_{2}$ to 94.93 yuan per tonne of $\mathrm{CO}_{2}, 143.97$ yuan per ton of $\mathrm{CO}_{2}$, and 185.59 yuan per ton of $\mathrm{CO}_{2}$, depending on the country. For offshore wind power plants, the operational cost is 0.1 yuan per kWh and 0.12 yuan for every tone of electricity. Our kilowatt-hour energy. The rate of exchange stays at 
five yuan/0.0. Alternatively, 0.2 yuan/kWh CNY and the fundamental value of TGC 75. As a result, the operational value of $\mathrm{CO}_{2}$ and TGC is influenced by changes in variable operating expenses. Higher levels of $\mathrm{CO}_{2}$ and TGC are required to decrease the increased operating expenses associated with company start-up and maintenance on offshore platforms.

This application proved the effectiveness of offshore wind turbines and drew the attention of investors and government officials' attention. Sherman \& $\mathrm{Co}$ is a business with its headquarters in New York (2020). The table shows 3.13 yuan/kWh or 0.71 yuan $/ \mathrm{kWh}$, assuming a utilization rate of 90-99 per cent, the influence of utilization rate on LCOE, accurate carbon price, and TGC cost under different utilization rates, and the impact of utilization rate on LCOE, accurate carbon price, and TGC cost. This demonstrates that reduced energy production costs will lead to lower rates of energy consumption. For example, when comparing the financial impact of offshore wind power projects today to the economic impact of all offshore wind power projects in 2020, the $\mathrm{CO}_{2}$ value (TGC value) required for profit in 2020 is 673.46 yuan/ton $\mathrm{CO}_{2}, 284.22$ yuan/ton $\mathrm{CO}_{2}, 143$ and 97 yuan/ton $\mathrm{CO}_{2}$, and 673.46 yuan/ton $\mathrm{CO}_{2}$. The crucial TGC price is 685.18 yuan, and 296 yuan when the carbon dioxide utilization rate reaches 90 percent, 95 percent, 97 percent, and 99 percent yuan/ton carbon dioxide and the 12.21 yuan/ton carbon dioxide utilization rate is reached, respectively. Coal prices and TGC regulations, as a result, may be advantageous to them. Invest in offshore wind farms and get the rewards of doing so.

Finally, the capacity factor reflects the prospective status of offshore wind farms, which may impact the lifecycle cost of electricity by offshore wind turbines (Tu et al. 2019a; Sherman et al. 2020). It is recommended that the capacity factor be between 30 and 45 percent, according to the International Renewable Energy Organization (IRENA, 2020). It can be shown in Table 3 that by raising the average Levelized cost of electricity) of offshore wind generation from $30 \%$ to $45 \%$, the cost is lowered from RMB $1.06 / \mathrm{kWh}$ to RMB $0.76 / \mathrm{kWh}$. As the cost of energy generation declines, the capacity factor rises in proportion to it. If the cost of power generation for all offshore wind power projects is compared to that of FIS, the cost of power generation for all offshore wind power projects in 2020 will be RMB 487.02/tonne $\mathrm{CO}_{2}$, $\mathrm{RMB} 272.55 /$ tonne $\mathrm{CO}_{2}$, $\mathrm{RMB} 143.97 /$ tonne $\mathrm{CO}_{2}, \mathrm{RMB} 41.52 / \mathrm{CO}_{2}$ and TGC. The critical tonnage is 498.82 yuan, 284.51 yuan, and 156.01 yuan for the first, second, and third places. As coal costs continue to increase and TGC rules become more stringent, offshore wind farms are becoming an increasingly appealing source of renewable power. Determine the cost of energy generated by offshore wind turbines. Among the topics covered in Part 4 of the Covid-19 pandemic is the economics of offshore wind power, while Part 3 examines the profitability of offshore wind power provided by specific technologies. On the fifth page, we look at the impact of green finance on lowering the total cost of ownership of offshore wind farms. The influence of the policy mixes on green capital and the approach for increasing the profitability of offshore wind power projects must be tailored to the actual cohabitation of policy instruments. Whether or not Covid-19 will influence offshore wind power projects/life cycle cost of offshore wind farms. Compared to 2014, the average fixed electricity cost (LCOE) of wind generation has decreased considerably, falling from RMB $0.86 / \mathrm{kWh}$ to RMB 0.72/kWh in 2016, representing a 16.17 percent decrease year-on-year. Consequently, the offshore wind turbine sector has been suffering losses 
since the development of Covid-19, which has resulted in a decrease in wind turbine efficiency and an increase in the price of offshore wind turbines.

\section{Conclusions}

The growth of offshore wind power is essential to the world's ability to meet its $\mathrm{CO}_{2}$ reduction objectives and change its energy sector in the following years. For its part, the COVID-19 epidemic has slowed or completely halted the building of offshore wind turbines, resulting in higher construction costs and a scarcity of offshore wind turbines on the market. In this particular example, the cost of offshore wind energy and production investment has grown considerably after the changeover to COVID-19, which has hampered the development of offshore wind power. Because it is the sole government instrument available, green finance may assist offshore wind power projects to reduce rising production costs and increase their profitability. This research aims to determine whether and how green finance options may be used to mitigate the economic impact of the COVID-19 epidemic on offshore wind power production. Currently, the United States is highly interested in offshore wind energy. The life cycle costs of 97 offshore wind energy projects have been estimated. This study, which ran from 2014 to 2020, examined LCOE projects completed before and after the COVID-19 epidemic to determine if the pandemic influenced LCOE offshore wind energy projects. The LCOE calculations include the inclusion of green financing legislation (such as marketable green assets, renewable energy credits, and green quotas) to determine the influence on the profitability of low-cost-of-energy (LCOE) and offshore wind farms. These findings may substantially impact decision-makers who are attempting to enhance green financing and offshore wind energy resource development following the COVID-19 epidemic. The cost of offshore wind energy generation has been decreased significantly. Electricity rates decreased by 15.16 percentage points between 2014 and 2019, going from 0.86 yuan/kWh to 0.72 yuan/kWh in 2014.

Please note that the cost of offshore wind turbines is an estimate based on current energy costs in 2020, starting at 8.71 per cent of COVID-19-epidemic levels. Daraus is part of the COVID-19 outbreak, and he invests in renewable energy and offshore surfing. However, some of the most prevalent causes of longterm outbreaks, such as the COVID-19 pandemic, are publicly publicized, and the number of COVID-19 episodes worldwide continues to rise. I do not think investing in energy-saving measures would help you establish long-term strategies and strategic policies to combat the COVID-19 epidemic.

Green finance policies, such as carbon dioxide ownership, relevant green certificates, and green credits, can be used to obtain cash or financing for a project's entire cost, which is typically outside the window. Green finance in China has made its way into the classrooms of youngsters. In offshore wind farms, this straightforward political tactic is familiar, accessible, and inexpensive. Short-term plans, as well as corporate and financial security strategies, can all be combined. However, authorities may not punish investments in offshore windows during the COVID-19 epidemic because FIS has not been allowed in recent years. 
Many missing data pieces, such as cost-effectiveness, capacity factors, and offshore wind farms, will be accompanying the major funding plan behind the COVID-19 epidemic. Aside from maintenance expenses, the tight shutdown of offshore wind turbines, capacity factors, and substantial financial resources are all required. These fundamental disparities are incredible and may vary in magnitude with the offshore development of offshore wind power technologies. For politicians, this outcome has significant political implications. We will ensure that various policies are implemented by promoting offshore wind projects in various regions of China. In addition, the learning effect is critical for lowering wind energy costs, which the learning rate and future capacity must control. The cost of offshore wind farms may be raised by giving firms clear finance regulations, technical assistance, and offshore wind energy technologies.

Both sides will have a strategic strategy that is centered on this outcome. Short-term, the regulators should promote offshore wind energy's participation in the national emissions trading market while also expanding the availability of green loans for subsidizing offshore wind energy investments. Offshore Wind energy entrenchment's advantages will be fleeting during the COVID-19 outbreak. $\mathrm{CO}_{2}$ offshore wind turbine controllers and specific offshore wind turbines from domestic market brands will be offset at that point. You can receive inexpensive finance and comprehensive offshore window leasing in addition to green credit investors.

R\&D funding will be increased in the long run to develop offshore wind energy technologies. Despite the continuous decrease in the cost of offshore wind power in China, the country still confronts several challenges in attaining the same price as conventional coal, including high operating and maintenance expenses and high investment costs. According to our findings, the cost of operation and maintenance, the cost of consumption, and the capacity of offshore wind turbines are the three major elements that influence the efficacy of green finance policies. To promote R\&D investment and general technical innovation in the offshore wind power business, the government should give R\&D subsidies and tax relief. This will improve utilization efficiency and reduce operational costs and finances. In this approach, gridconnected parity between renewable and conventional coal-based electricity reached sooner, contributing more significantly to China's carbon dioxide neutralization objective.

\section{Declarations}

\section{Ethical Approval and Consent to Participate}

The authors declare that they have no known competing financial interests or personal relationships that seem to affect the work reported in this article. We declare that we have no human participants, human data or human tissues.

\section{Consent for Publication}

We do not have any individual person's data in any form.

\section{Author Contribution}


Riaz Hussain Jamali; Conceptualization, Data curation, Methodology, Writing - original draft. Amanullah Bughio; Data curation, Visualization. Ghansham Das; review \& editing. Rizwan Jamali; Writing - review \& editing and software. Shova Niroula; Visualization, supervision, editing, Zulfiqar Ali Baloch; Methodology, Data curation, Visualization

\section{Funding}

This research did not receive any specific funding from public, commercial or non-profit sector funding agencies.

\section{Competing interest statement}

We declare that there is no conflict of interest.

\section{Availability of data and materials}

The data that support the findings of this study are openly available on request.

\section{References}

1. Anser MK, Yousaf Z, Zaman K et al (2020) Determination of resource curse hypothesis in mediation of financial development and clean energy sources: Go-for-green resource policies. Resour Policy. https://doi.org/10.1016/j.resourpol.2020.101640

2. Banerjee R, Mishra V, Maruta AA (2021) Energy poverty, health and education outcomes: Evidence from the developing world. Energy Econ 101:105447. https://doi.org/10.1016/j.eneco.2021.105447

3. Barbier EB (2020) Greening the post-pandemic recovery in the G20. Environ Resour Econ 76:685-703

4. Bosch J, Staffell I, Hawkes AD (2019) Global levelised cost of electricity from offshore wind. Energy 189:116357

5. Bourcet C, Bovari E (2020) Exploring citizens' decision to crowdfund renewable energy projects: Quantitative evidence from France. Energy Econ 88:104754

6. Broto VC, Kirshner J (2020) Energy access is needed to maintain health during pandemics. Nat Energy 5:419-421

7. Chen K, Ren Z, Mu S et al (2020) Integrating the Delphi survey into scenario planning for China's renewable energy development strategy towards 2030. Technol Forecast Soc Change 158:120157

8. Cui Q, Liu Y, Ali T et al (2020) Economic and climate impacts of reducing China's renewable electricity curtailment: A comparison between CGE models with alternative nesting structures of electricity. Energy Econ 91:104892

9. Da Z, Xiliang Z, Jiankun H, Qimin C (2011) Offshore wind energy development in China: Current status and future perspective. Renew Sustain Energy Rev 15:4673-4684

10. Davidson MR, Zhang D, Xiong W et al (2016) Modelling the potential for wind energy integration on China's coal-heavy electricity grid. Nat Energy 1:1-7 
11. Dikau S, Volz U (2018) Central banking, climate change and green finance

12. Falcone PM, Sica E (2019) Assessing the opportunities and challenges of green finance in Italy: An analysis of the biomass production sector. Sustainability 11:517

13. Finance GI (2013) Green Investment Climate Country Profile-Vietnam

14. Ghorbanpour A, pooya A, Naji Azimi Z (2021) Application of green supply chain management in the oil Industries: Modeling and performance analysis. Mater Today Proc. https://doi.org/10.1016/j.matpr.2021.03.672

15. Gillingham KT, Knittel CR, Li J et al (2020) The Short-run and Long-run Effects of Covid-19 on Energy and the Environment. Joule 4:1337-1341

16. Grunewald P (2017) Renewable deployment: Model for a fairer distribution. Nat Energy 2:1-2

17. Hafner S, Jones A, Anger-Kraavi A, Pohl J (2020) Closing the green finance gap-A systems perspective. Environ Innov Soc Transitions 34:26-60

18. He Z, Xu S, Shen W et al (2016) Overview of the development of the Chinese Jiangsu coastal windpower industry cluster. Renew Sustain Energy Rev 57:59-71

19. Hosseini SE (2020) An outlook on the global development of renewable and sustainable energy at the time of COVID-19. Energy Res Soc Sci 68:101633

20. Ibiang YB, Mitsumoto H, Sakamoto K (2017) Bradyrhizobia and arbuscular mycorrhizal fungi modulate manganese, iron, phosphorus, and polyphenols in soybean (Glycine max (L.) Merr.) under excess zinc. Environ Exp Bot 137:1-13. https://doi.org/10.1016/j.envexpbot.2017.01.011

21. Irawan CA, Ouelhadj D, Jones D et al (2017) Optimisation of maintenance routing and scheduling for offshore wind farms. Eur J Oper Res 256:76-89

22. Kuzemko C, Bradshaw M, Bridge $G$ et al (2020) Covid-19 and the politics of sustainable energy transitions. Energy Res Soc Sci 68:101685

23. Li Y, Wu X-P, Li Q-S, Tee KF (2018) Assessment of onshore wind energy potential under different geographical climate conditions in China. Energy 152:498-511

24. Liang $Y$, Yu B, Wang $L$ (2019) Costs and benefits of renewable energy development in China's power industry. Renew energy 131:700-712

25. Ligus M (2014) Levelized Cost of Electricity (LCOE) of Renewable Energies in the Auctioning System in Poland. In: SGEM Conference on Political Sciences, Law, Finance, Economics and Tourism, Conference Proceedings. pp 435-442

26. Lin B, Zhu J (2019) Fiscal spending and green economic growth: Evidence from China. Energy Econ 83:264-271. https://doi.org/10.1016/j.eneco.2019.07.010

27. Lutzeyer S, Phaneuf DJ, Taylor LO (2018) The amenity costs of offshore wind farms: Evidence from a choice experiment. Energy Econ 72:621-639

28. Lv C, Bian B, Lee CC, He Z (2021) Regional gap and the trend of green finance development in China. Energy Econ 102:105476. https://doi.org/10.1016/j.eneco.2021.105476 
29. Mattar C, Guzmán-Ibarra MC (2017) A techno-economic assessment of offshore wind energy in Chile. Energy 133:191-205

30. Nicita A, Maggio G, Andaloro APF, Squadrito G (2020) Green hydrogen as feedstock: Financial analysis of a photovoltaic-powered electrolysis plant. Int J Hydrogen Energy 45:11395-11408

31. Ouyang X, Lin B (2014) Levelized cost of electricity (LCOE) of renewable energies and required subsidies in China. Energy Policy 70:64-73

32. Praveen RP, Keloth V, Abo-Khalil AG et al (2020) An insight to the energy policy of GCC countries to meet renewable energy targets of 2030. Energy Policy 147:111864

33. Quitzow R, Bersalli G, Eicke L et al (2021) The COVID-19 crisis deepens the gulf between leaders and laggards in the global energy transition. Energy Res Soc Sci 74:101981

34. Rehman E, Ikram M, Rehman S, Feng MT (2021) Growing green? Sectoral-based prediction of GHG emission in Pakistan: a novel NDGM and doubling time model approach. Environ Dev Sustain. https://doi.org/10.1007/s10668-020-01163-5

35. Rosenbloom D, Markard J (2020) A COVID-19 recovery for climate

36. Shafiee M, Finkelstein M, Bérenguer C (2015) An opportunistic condition-based maintenance policy for offshore wind turbine blades subjected to degradation and environmental shocks. Reliab Eng Syst Saf 142:463-471

37. Sherman P, Chen X, McElroy M (2020) Offshore wind: An opportunity for cost-competitive decarbonization of China's energy economy. Sci Adv 6:eaax9571

38. Singh SK, Giudice M, Del, Chierici R, Graziano D (2020) Green innovation and environmental performance: The role of green transformational leadership and green human resource management. Technol Forecast Soc Change. https://doi.org/10.1016/j.techfore.2019.119762

39. Sovacool BK, Del Rio DF, Griffiths S (2020) Contextualizing the Covid-19 pandemic for a carbonconstrained world: Insights for sustainability transitions, energy justice, and research methodology. Energy Res Soc Sci 68:101701

40. Sutherland BR (2019) Susceptibility of Renewables to Interest Rates. Joule 3:2597-2599

41. Tu Q, Betz R, Mo J et al (2019a) Achieving grid parity of wind power in China-Present levelized cost of electricity and future evolution. Appl Energy 250:1053-1064

42. Tu Q, Betz R, Mo J, Fan Y (2019b) The profitability of onshore wind and solar PV power projects in China-A comparative study. Energy Policy 132:404-417

43. Tu Q, Mo J, Liu Z et al (2021) Using green finance to counteract the adverse effects of COVID-19 pandemic on renewable energy investment-The case of offshore wind power in China.Energy Policy 112542

44. Volz U (2018) Fostering green finance for sustainable development in Asia

45. Wiser R, Jenni K, Seel J et al (2016) Expert elicitation survey on future wind energy costs. Nat Energy $1: 1-8$ 
46. Yaghoubian I, Ghassemi S, Nazari M et al (2021) Response of physiological traits, antioxidant enzymes and nutrient uptake of soybean to Azotobacter Chroococcum and zinc sulfate under salinity. South African J Bot 143:42-51. https://doi.org/10.1016/j.sajb.2021.07.037

47. Yoshino N, Taghizadeh-Hesary F, Otsuka M (2021) Covid-19 and optimal portfolio selection for investment in sustainable development goals. Financ Res Lett 38:101695

48. Yuan J (2016) Wind energy in China: Estimating the potential. Nat Energy 1:1-2

49. Zhang D, Mohsin M, Rasheed AK et al (2021) Public spending and green economic growth in BRI region: Mediating role of green finance. Energy Policy. https://doi.org/10.1016/j.enpol.2021.112256

50. Zhang D, Zhang Z, Managi S (2019) A bibliometric analysis on green finance: Current status, development, and future directions. Financ Res Lett. https://doi.org/10.1016/j.frl.2019.02.003

51. Zhang M, Liu L, Wang Q, Zhou D (2020) Valuing investment decisions of renewable energy projects considering changing volatility. Energy Econ 92:104954

52. Zhao Z-Y, Chen Y-L, Chang R-D (2016) How to stimulate renewable energy power generation effectively?-China's incentive approaches and lessons. Renew energy 92:147-156

53. Zhao Z, Yan H, Zuo J et al (2013) A critical review of factors affecting the wind power generation industry in China. Renew Sustain Energy Rev 19:499-508

54. Zhou D, Ding H, Wang Q, Su B (2021) Literature review on renewable energy development and China's roadmap. Front Eng Manag 8:212-222

\section{Tables}

Table $6 \& 7$ are not available with this version.

\section{Figures}




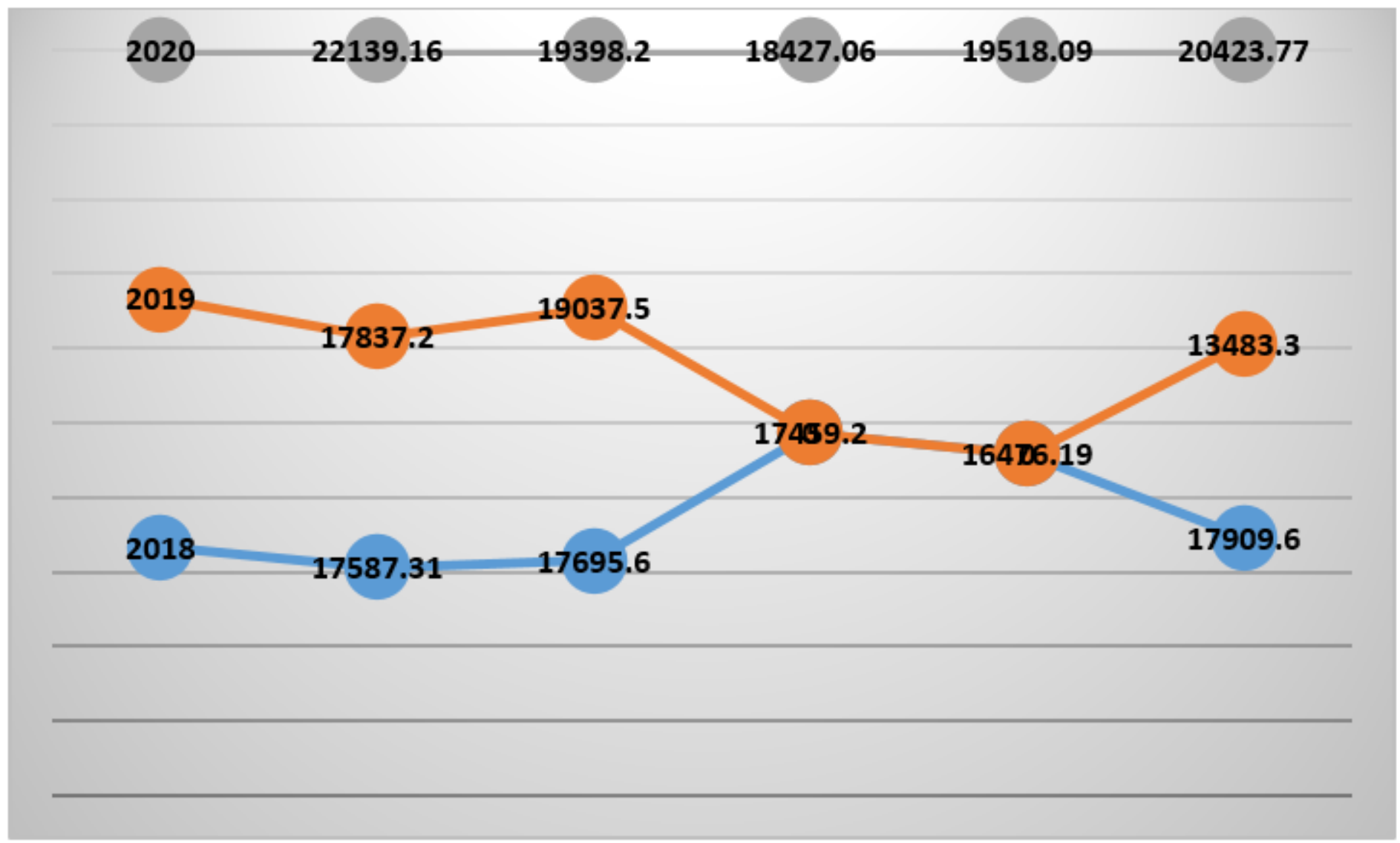

Figure 1

Wind power projects. 


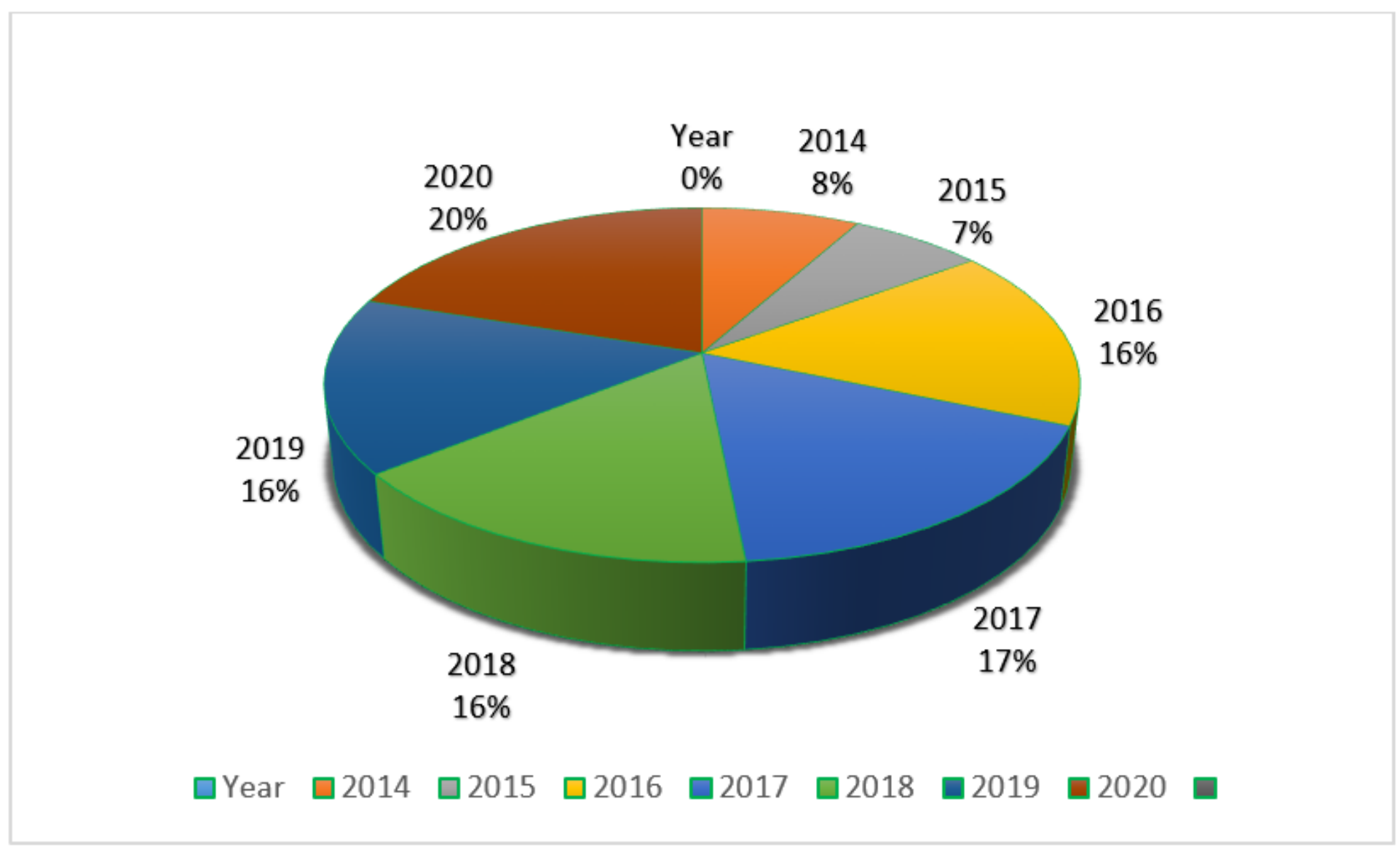

Figure 2

Wind energy investment costs from 2000 to 2020. 


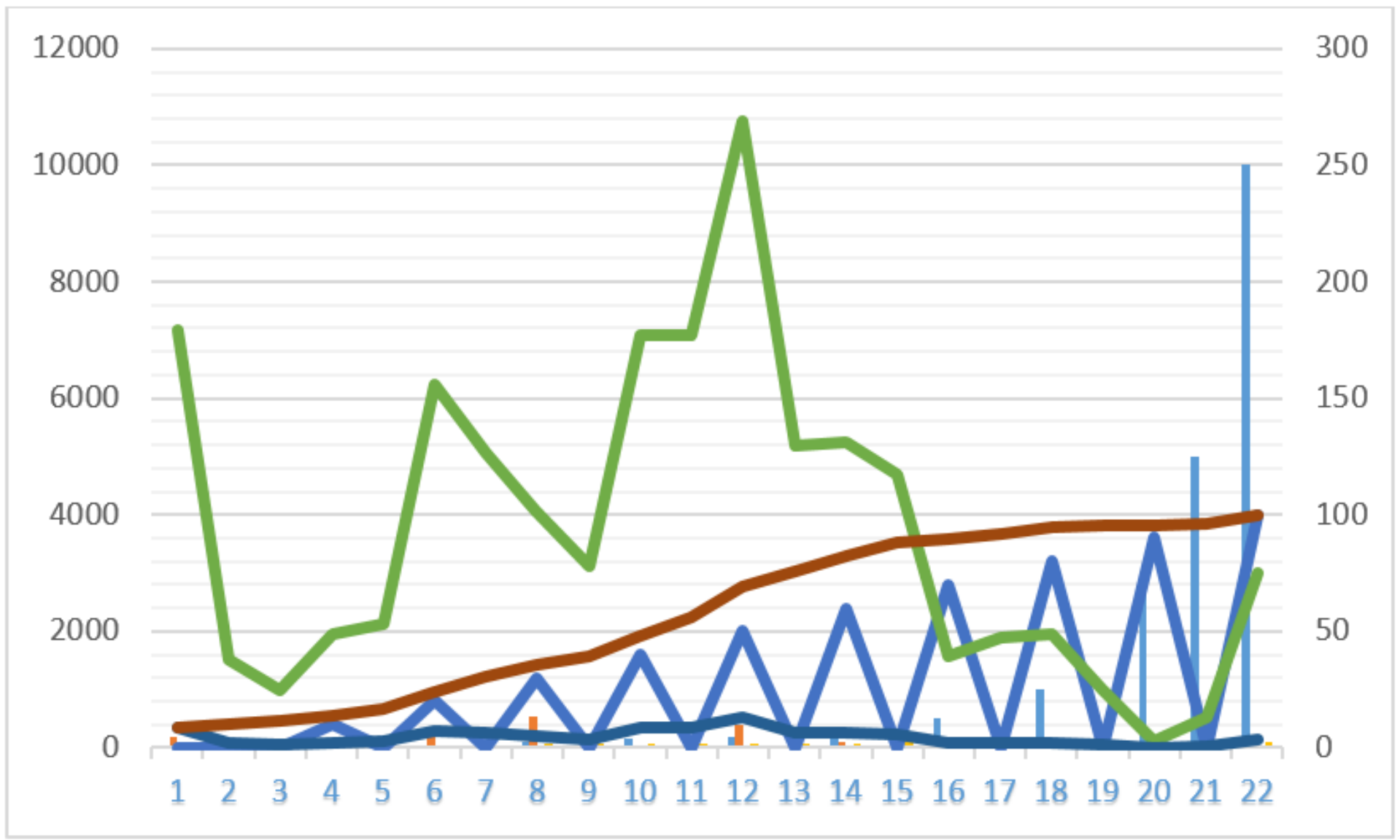

Figure 3

Shows the proportion of responders that paid for their COVID-19 vaccine. 


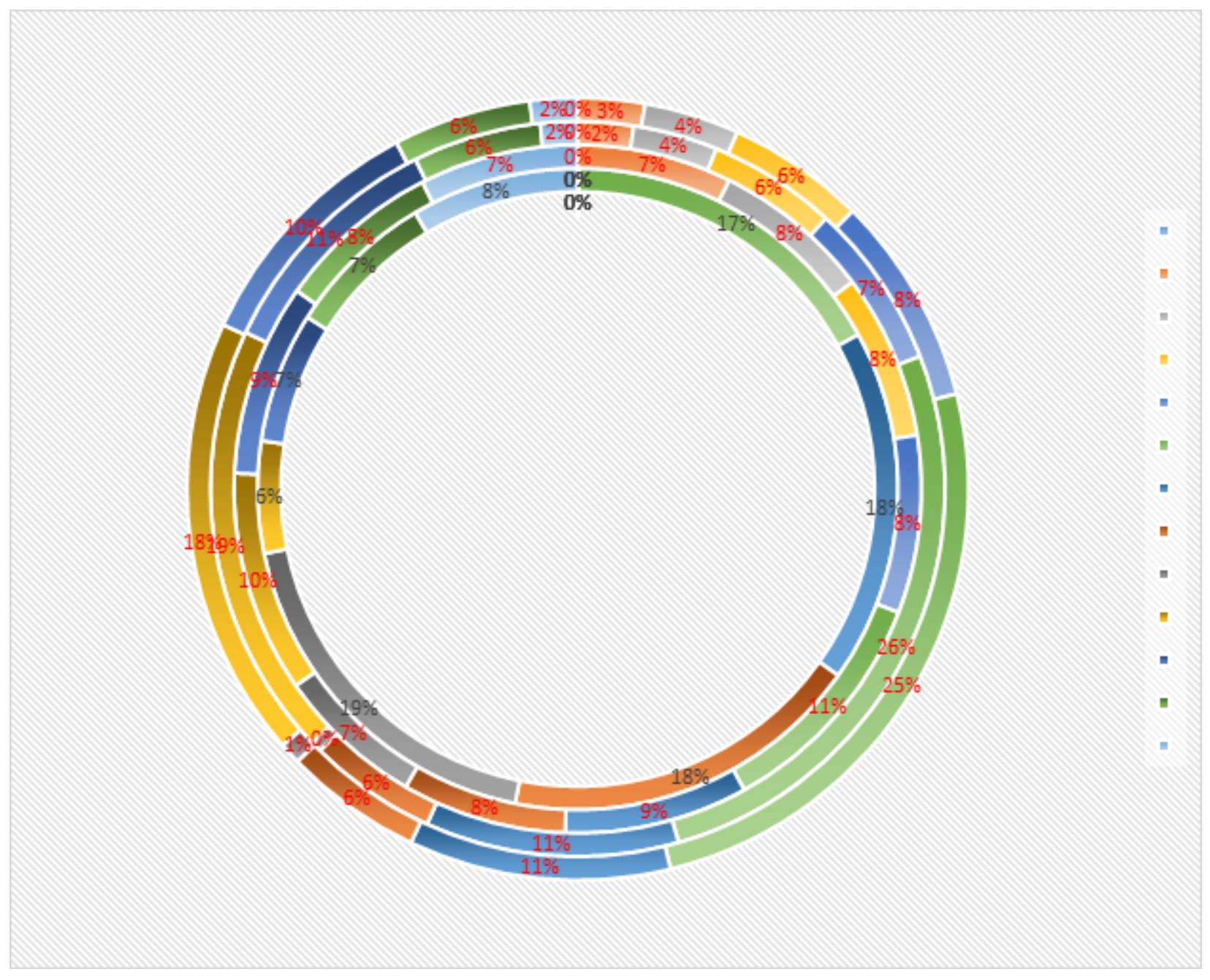

Figure 4

Parameter sensitivity analysis. 